\title{
Annual Transportation Report for \\ Radioactive Waste Shipments to and from the Nevada Test Site
}

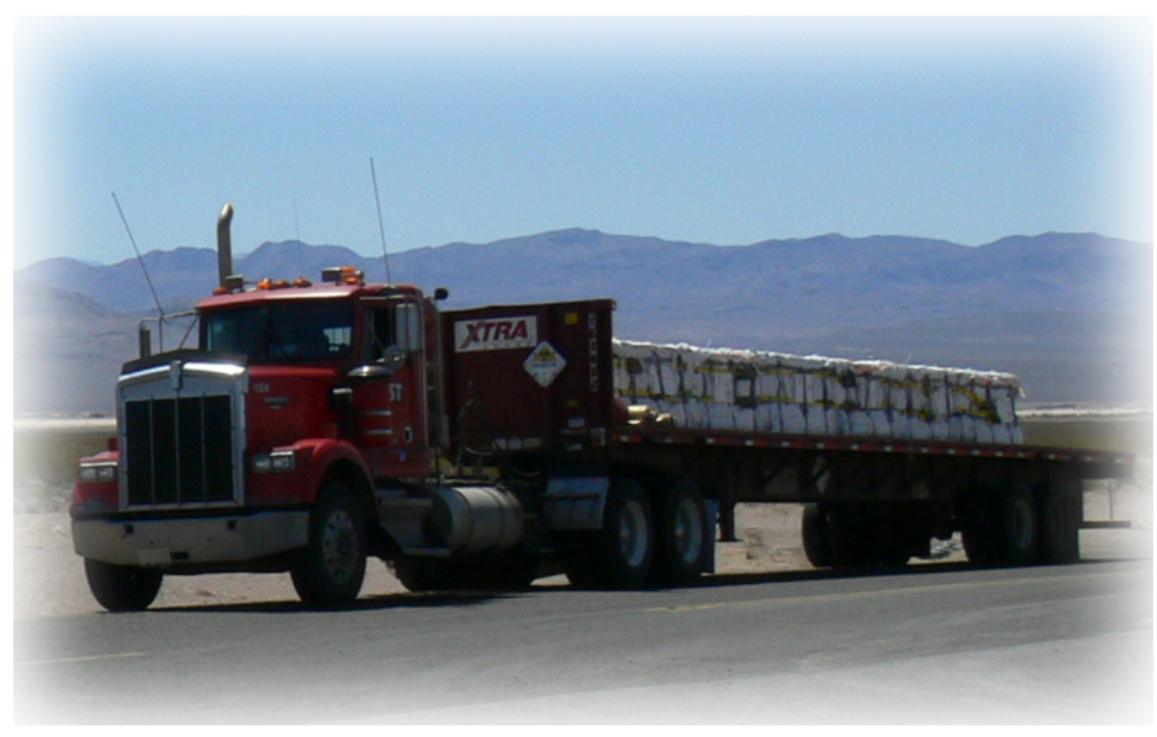

Fiscal Year 2007

December 2007

\section{U.S. Department of Energy}

National Nuclear Security Administration Nevada Site Office 
Available for sale to the public from-

U.S. Department of Commerce

National Technical Information Service

5285 Port Royal Road

Springfield, VA 22161

Phone: 800.553.6847

Fax: 703.605.6900

Email: orders@ntis.gov

Online ordering: http://www.ntis.gov/ordering.htm

Available electronically at http://www.osti.gov/bridge

Available for a processing fee to U.S. Department of Energy and its contractors, in paper, from-

U.S. Department of Energy

Office of Scientific and Technical Information

P.O. Box 62

Oak Ridge, TN 37831-0062

Phone: 865.576 .8401

Fax: 865.576.5728

Email: reports@adonis.osti.gov 


\title{
ANNUAL TRANSPORTATION REPORT FY 2007
}

\author{
Radioactive Waste Shipments \\ to and from the Nevada Test Site (NTS)
}

December 2007

United States Department of Energy National Nuclear Security Administration

Nevada Site Office

Las Vegas, Nevada 
This page intentionally left blank 


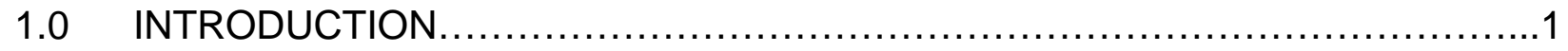

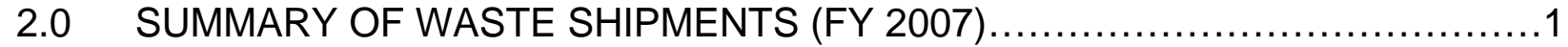

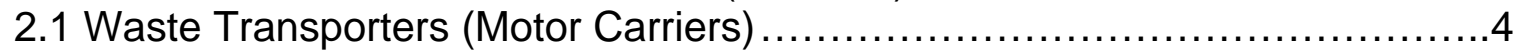

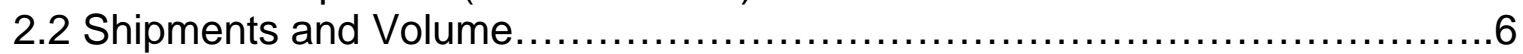

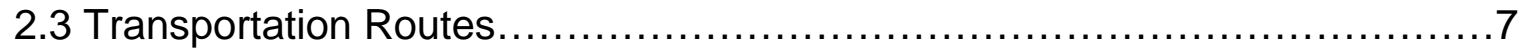

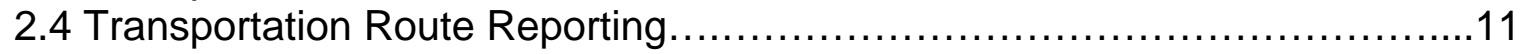

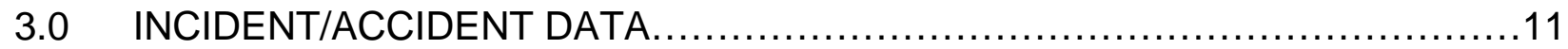

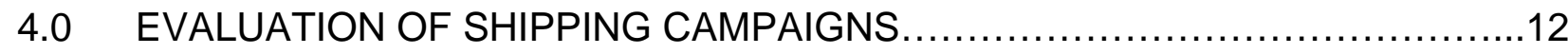

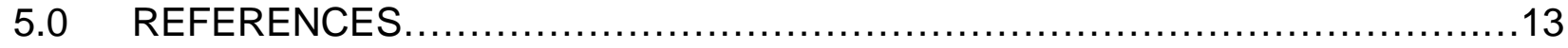

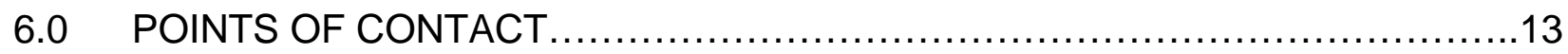

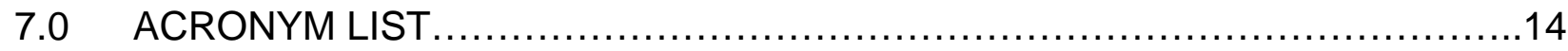

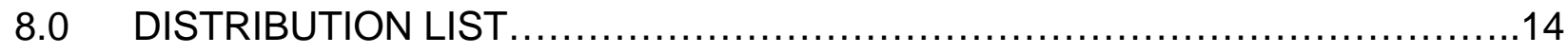


This page intentionally left blank 


\subsection{INTRODUCTION}

In February 1997, the U.S. Department of Energy, Nevada Operations Office (now known as the Nevada Site Office) issued the Mitigation Action Plan which addressed potential impacts described in the "Final Environmental Impact Statement for the Nevada Test Site and Off-Site Locations in the State of Nevada" (DOE/EIS 0243). The U.S. Department of Energy, Nevada Operations Office committed to several actions, including the preparation of an annual report, which summarizes waste shipments to and from the Nevada Test Site (NTS) Radioactive Waste Management Site (RWMS) at Area 5. No shipments were disposed of at Area 3 in fiscal year (FY) 2007. This document satisfies requirements regarding low-level radioactive waste (LLW) and mixed low-level radioactive waste (MLLW) transported to or from the NTS during FY 2007. In addition, this document provides shipment, volume, and route information on transuranic (TRU) waste shipped from the NTS to the Waste Isolation Pilot Plant (WIPP) near Carlsbad, New Mexico. This outbound shipping campaign began in FY 2004.

This report has been prepared in accordance with the specifications contained in Section 4.1.1 (Commitments) of the "NTS Environmental Impact Statement, Mitigation Action Plan" (February 1997). Tabular summaries are provided which include the following data:

- $\quad$ Sources of and carriers for LLW and MLLW shipments to or from the NTS;

- $\quad$ Number and external volume of LLW and MLLW shipments;

- Identification of highway routes used by carriers; and

- Incident/accident data applicable to LLW and MLLW shipments.

\subsection{SUMMARY OF WASTE SHIPMENTS (FY 2007)}

Inbound/Off-site LLW

A total of $734,047 \mathrm{ft}^{3}$ of LLW was disposed at the NTS RWMS in FY 2007, consisting of 1,002 inbound/off-site shipments, from 16 approved generators. These shipments were transported on 15 approved motor carriers (including government vehicles).

Inbound/Off-site MLLW

A total of 134 MLLW inbound/off-site shipments were received at the NTS in FY 2007 , from seven (7) approved generators, totaling 140,144 $\mathrm{ft}^{3}$. These shipments were transported on nine (9) approved motor carriers.

Total Inbound/Off-site LLW and MLLW

A total of $874,191 \mathrm{ft}^{3}$ of LLW was disposed at the NTS in FY 2007 by 17 approved off-site generators in 1,136 shipments, transported on 16 approved motor carriers.

On-site LLW

Two approved on-site generators disposed $59,469 \mathrm{ft}^{3}$ of LLW in 110 on-site transfers during FY 2007. Government (contractor) vehicles were used for these transfers. 
On-site MLLW

Twenty on-site transfers accounted for $10,169 \mathrm{ft}^{3}$ of MLLW being disposed by two (2) on-site generators in FY 2007.

Outbound/Off-site LLW

No outbound/off-site shipments of LLW were made in FY 2007 by NTS tenants. However, one shipment containing 1,359 $\mathrm{ft}^{3}$ of LLW that was shipped to the NTS by the Portsmouth Gaseous Diffusion Plant in FY 2007 was returned by the generator due to non-compliance, using an approved carrier.

Outbound/Off-site MLLW

Ten outbound shipments containing 3,020 $\mathrm{ft}^{3}$ of MLLW were made from the NTS. National Security Technologies, LLC (NSTec), the Management and Operations contractor at the NTS, made one (1) shipment to Waste Control Specialists in Andrews, Texas, eight (8) shipments to EnergySolutions near Clive, Utah and one (1) to Permafix ME\&C in Tennessee.

Outbound/Off-site Transuranic (TRU) Waste

No TRU waste shipments were made from the NTS to WIPP in FY 2007.

Table 1 provides a summary of inbound, outbound, and on-site shipments for FY 2007. Names and codes for approved generators and carriers used in this report are located in Tables 2 and 3, respectively.

Table 1. FY 2007 NTS Inbound, Outbound and On-site Summary Information

\begin{tabular}{|c|c|c|c|c|c|}
\hline Inbound & $\begin{array}{c}\text { Off-site } \\
\text { Generators }\end{array}$ & $\begin{array}{c}\text { NTS } \\
\text { Generators }\end{array}$ & $\begin{array}{c}\text { Approved } \\
\text { Carriers }\end{array}$ & Shipments & Volume $\mathrm{ft}^{3}$ \\
\hline LLW (off-site) & 16 & 1 & 15 & 1,002 & 734,047 \\
\hline MLLW (off-site) & 7 & 0 & 9 & 134 & 140,144 \\
\hline LLW (on-site) & 0 & 2 & 1 & 110 & 59,469 \\
\hline MLLW (on-site) & 0 & 2 & 1 & 20 & 10,169 \\
\hline Outbound & $\begin{array}{c}\text { Off-site } \\
\text { Generators }\end{array}$ & $\begin{array}{c}\text { NTS } \\
\text { Generators }\end{array}$ & $\begin{array}{l}\text { Approved } \\
\text { Carriers }\end{array}$ & Shipments & Volume $\mathrm{ft}^{3}$ \\
\hline LLW & $1^{1}$ & 0 & 0 & 1 & 1,359 \\
\hline MLLW & 0 & 1 & $4^{12}$ & 10 & 3,020 \\
\hline TRU & 0 & 0 & 0 & 0 & 0 \\
\hline
\end{tabular}

$\underline{1}$ / Portsmouth Gaseous Diffusion Plant LLW shipment POL0715 (1,359 $\left.\mathrm{ft}^{3}\right)$ was returned to generator via Specialty Transport.

2/ CAST Transportation, MP Environmental Services, Specialty Transport, and Tri-State Motor Transit were utilized for MLLW shipments. 
Table 2. List of Approved Generators Shipping To/From the NTS

\begin{tabular}{|l|c|}
\hline \multicolumn{1}{|c|}{ APPROVED GENERATOR, STATE } & $\begin{array}{c}\text { GENERATOR } \\
\text { CODE }\end{array}$ \\
\hline BECHTEL JACOBS OAK RIDGE, TN & OR \\
\hline BOEING ROCKETDYNE, CA & BN \\
\hline BWXT Y-12 PLANT, TN & BW \\
\hline DURATEK, OAK RIDGE, TN & DR \\
\hline FOSTER WHEELER, TN & $\mathrm{FW}$ \\
\hline IDAHO NATIONAL LABORATORY, ID & $\mathrm{IN}$ \\
\hline LAWRENCE LIVERMORE NATIONAL LAB, CA & $\mathrm{LL}$ \\
\hline NATIONAL SECURITY TECHNOLOGIES, NV AND OK 3 3l & $\mathrm{DP}$ \\
\hline NUCLEAR FUEL SERVICES, TN & $\mathrm{NF}$ \\
\hline PADUCAH GASEOUS DIFFUSION PLANT, TN & $\mathrm{PD}$ \\
\hline PANTEX PLANT, TX & $\mathrm{PX}$ \\
\hline PERMAFIX (M\&CE), TN & $\mathrm{PF}$ \\
\hline PORTSMOUTH GASEOUS DIFFUSION PLANT, OH & $\mathrm{PO}$ \\
\hline PRINCETON PLASMA PHYSICS LAB, NJ & $\mathrm{PL}$ \\
\hline SANDIA NATIONAL LAB, NM & $\mathrm{SA}$ \\
\hline STOLLER-NAVARRO JOINT VENTURE, NV 4 II & $\mathrm{IT}$ \\
\hline WASHINGTON SAVANNAH RIVER, SC & $\mathrm{SR}$ \\
\hline WEST VALLEY DEMONSTARTION PROJECT, NY & $\mathrm{WV}$ \\
\hline
\end{tabular}

3/ On-site, Inbound and Outbound

41 On-site Only

Table 3. List of Approved Motor Carriers Utilized in FY 2007

\begin{tabular}{|l|c|}
\hline \multicolumn{1}{|c|}{ APPROVED MOTOR CARRIER } & $\begin{array}{c}\text { CARRIER } \\
\text { CODE }\end{array}$ \\
\hline AJ METLER & MAJH \\
\hline BUFFALO FUEL COMPANY & BFUI \\
\hline CAST TRANSPORTATION & COLO \\
\hline FEDEX CUSTOM CRITICAL & FDCC \\
\hline FLUID TRANSPORTS & FLAI \\
\hline GOVERNMENT VEHICLE & GT+ \\
\hline HITTMAN TRANSPORT & HITT \\
\hline HUBBARD TRUCKING & HUB+ \\
\hline INTERSTATE VENTURES & ITSV \\
\hline LANDSTAR LIGON & LIGS \\
\hline LANDSTAR RANGER & LRGR \\
\hline MP ENVIRONMENTAL & MPES \\
\hline R\&R TRUCKING & RRUK \\
\hline SOUTHERN FREIGHT LOGISITICS & SFLG \\
\hline SPECIALTY TRANSPORT & SPLC \\
\hline TAG TRANSPORT & TAGD \\
\hline TRI-STATE MOTOR TRANSIT & TSMT \\
\hline
\end{tabular}

$\underline{5 /}$ Portsmouth Gaseous Diffusion Plant LLW shipment POL0715 (1,359 ft $\left.{ }^{3}\right)$ was returned to generator via Specialty Transport. 


\subsection{Waste Transporters (Motor Carriers)}

Generators often use more than one motor carrier to facilitate their shipments. Table 4 identifies each generator and the corresponding carrier(s) utilized for transport of inbound, off-site LLW shipments. Table 5 identifies each generator and the corresponding carrier(s) utilized for transport of outbound, off-site shipments of MLLW. Table 6 identifies each generator and the corresponding carrier(s) utilized for transport of on-site transfers of LLW and MLLW. Motor carriers operate in compliance with regulations located in Title 49 Code of Federal Regulations, "Transportation," and are selected by the generator. 
Table 4. Waste Transporters Utilized by Generators for Inbound Shipments (number of shipments)

\begin{tabular}{|c|c|c|c|c|c|c|c|c|c|c|c|c|c|c|c|c|c|}
\hline & $\mathrm{BN}$ & BW & DR & FW & IN & LL & DP & NF & OR & PD & $P X$ & PF & $\mathrm{PO}$ & $\mathrm{PL}$ & SA & SR & WV \\
\hline MAJH & & 97 & & & & & 8 & 7 & 28 & & & 4 & 80 & & & & \\
\hline BFUI & & & & & & & & & & & & & & & & & 119 \\
\hline COLO & & & & & & & & & & & & & & & & & 190 \\
\hline FDCC & & & & & & & & & & & & & & & & 1 & \\
\hline FLAI & & & & & & & & & & & 2 & & & & 12 & & \\
\hline GT+ & & & & & & 12 & & & & & & & & & & & \\
\hline HITT & & & 1 & & 6 & 1 & & & 1 & & & 23 & & & & 7 & 8 \\
\hline HUB + & & & & & & & & & & & & & 19 & & & & \\
\hline ITSV & & & & 4 & & & & 4 & & & & & & & & & 175 \\
\hline LIGS & & & & & & 3 & 4 & & & & & & & & & & \\
\hline LRGR & & & & & & & & & & & & & & & & 1 & \\
\hline MPES & 18 & & & & & 9 & 26 & & & & & & & & & & \\
\hline RRUK & & & & & & 6 & 20 & 5 & & & & & 41 & & & & \\
\hline SFLG & & & & & & & & 48 & & & & & & & & & \\
\hline TAGD & & & & & & & & & 2 & & & & & & & & \\
\hline TSMT & & 37 & & & 52 & 15 & 13 & & & 1 & & 3 & 7 & 1 & & 15 & \\
\hline
\end{tabular}

Table 5. Waste Transporters Utilized by NTS Approved Generators for Outbound Shipments

\begin{tabular}{|l|c|c|}
\hline & DP & PO \\
\hline COLO & 3 & \\
\hline TSMT & 1 & \\
\hline MPES & 5 & \\
\hline SPLC & 1 & $1^{-6 /}$ \\
\hline
\end{tabular}

6/ Portsmouth Gaseous Diffusion Plant LLW shipment POL0715 (1,359 ft $\left.{ }^{3}\right)$ was returned to generator via Specialty Transport.

Table 6. Waste Transporters Utilized by NTS Generators for On-site Transfers

\begin{tabular}{|l|l|l|}
\hline & DP & IT \\
\hline GT+ & 97 & 33 \\
\hline
\end{tabular}




\subsection{Shipments and Volume}

Table 7 provides a summary of all LLW, MLLW, and TRU waste shipments, including volume, to and from the NTS during FY 2007.

Table 7. Shipments and Volumes of Waste Sent To and From the NTS (FY 2007)

\begin{tabular}{|c|c|c|c|c|c|c|}
\hline Off-site Inbound Low Level \& Mixed & \multicolumn{5}{|c|}{ Shipments by Quarter } & \multirow{2}{*}{$\begin{array}{l}\text { Volume } \\
(\mathrm{ft} 3)\end{array}$} \\
\hline Generator Code & $1 \mathrm{st}$ & 2 nd & $3 \mathrm{rd}$ & $4^{\text {th }}$ & Total & \\
\hline $\mathrm{BN}$ & 9 & 7 & 0 & 2 & 18 & 11,740 \\
\hline BW & 15 & 31 & 42 & 46 & 134 & 148,822 \\
\hline$\overline{D R}$ & 0 & $\overline{0}$ & 1 & 0 & 1 & 110 \\
\hline FW & 0 & 0 & 4 & 0 & 4 & 5,933 \\
\hline IN & 6 & 10 & 14 & 28 & 58 & 28,022 \\
\hline $\mathrm{LL}$ & 10 & 18 & 13 & 5 & 46 & 48,217 \\
\hline $\mathrm{DP}$ & 0 & 41 & 4 & 26 & 71 & 70,017 \\
\hline $\mathrm{NF}$ & 11 & 18 & 13 & 22 & 64 & 72,232 \\
\hline OR & 9 & 1 & 4 & 17 & 31 & 32,395 \\
\hline $\mathrm{PD}$ & 0 & 0 & 1 & 0 & 1 & 960 \\
\hline $\mathrm{PX}$ & 0 & 0 & 1 & 1 & 2 & 2,203 \\
\hline $\mathrm{PF}$ & 1 & 19 & 9 & 1 & 30 & 24,804 \\
\hline $\mathrm{PO}$ & 2 & 24 & 78 & 43 & 147 & 172,054 \\
\hline $\mathrm{PL}$ & $\overline{0}$ & $\overline{0}$ & 0 & 1 & 1 & 409 \\
\hline $\mathrm{SA}$ & 0 & 3 & 3 & 6 & 12 & 5,058 \\
\hline$\overline{S R}$ & 21 & 0 & 2 & 1 & 24 & 2,710 \\
\hline $\mathrm{WV}$ & 47 & 34 & 140 & 271 & 492 & 248,505 \\
\hline Totals & 131 & 206 & 329 & 470 & 1,136 & 874,191 \\
\hline On-site Low Level Waste Transfers & \multicolumn{5}{|c|}{ Shipments by Quarter } & Volume \\
\hline Generator Code & $1 \mathrm{st}$ & 2nd & 3 rd & $4^{\text {th }}$ & Total & $(\mathrm{ft} 3)$ \\
\hline $\mathrm{DP}$ & 6 & 74 & 1 & 7 & 88 & 35,957 \\
\hline IT & 1 & 0 & 1 & 20 & 22 & 23,512 \\
\hline Total & 7 & 74 & 2 & 27 & 110 & 59,469 \\
\hline On-site Mixed Low-Level Waste Transfers & \multicolumn{5}{|c|}{ Shipments by Quarter } & Volume \\
\hline & $1 \mathrm{st}$ & 2nd & $3 \mathrm{rd}$ & $4^{\text {th }}$ & Total & $(\mathrm{ft} 3)$ \\
\hline $\mathrm{DP}$ & 0 & 0 & 0 & 9 & 9 & 2,745 \\
\hline IT & 0 & 0 & 0 & 11 & 11 & 7,424 \\
\hline & 0 & 0 & 0 & 20 & 20 & 10,169 \\
\hline $\begin{array}{l}\text { Outbound Mixed Low-Level Waste } \\
\text { Shipments }\end{array}$ & \multicolumn{5}{|c|}{ Shipments by Quarter } & Volume \\
\hline Generator Code & $1 \mathrm{st}$ & 2 nd & $3 \mathrm{rd}$ & $4^{\text {th }}$ & Total & $(\mathrm{ft} 3)$ \\
\hline $\mathrm{DP}$ & 2 & 1 & 0 & 7 & 10 & 3,020 \\
\hline Outbound Low-Level Waste Shipments & \multicolumn{5}{|c|}{ Shipments by Quarter } & Volume \\
\hline Generator Code & $1 \mathrm{st}$ & 2nd & $3 \mathrm{rd}$ & $4^{\text {th }}$ & Total & (ft3) \\
\hline $\mathrm{PO}$ & 0 & 0 & 0 & 1 & 1 & 1,359 \\
\hline Outbound Transuranic Waste Shipments & \multicolumn{5}{|c|}{ Shipments by Quarter } & Volume \\
\hline Generator Code & $1 \mathrm{st}$ & 2nd & $3 \mathrm{rd}$ & $4^{\text {th }}$ & Total & $(\mathrm{ft} 3)$ \\
\hline DP & 0 & $\mathbf{0}$ & 0 & 0 & 0 & 0 \\
\hline
\end{tabular}




\subsection{Transportation Routes}

Seventeen out-of-state approved generators shipped LLW and MLLW to the NTS for disposal in FY 2007. NSTec initiated 41 shipments from Gore, Oklahoma, four (4) shipments from Creech Air Force Base in Nevada, and 26 shipments from the Tonopah Test Range in Nevada, to the NTS in FY 2007. Table 8 provides specific routes utilized by each generator and the number of shipments in FY 2007.

Figures 1 and 2 provide graphical interpretations of the general cross country and regional transportation routes, respectively. 
Figure 1 - FY 2007 National

Low-Level, Mixed Low-Level, and Transuranic Waste General Transportation Routes to/from the Nevada Test Site

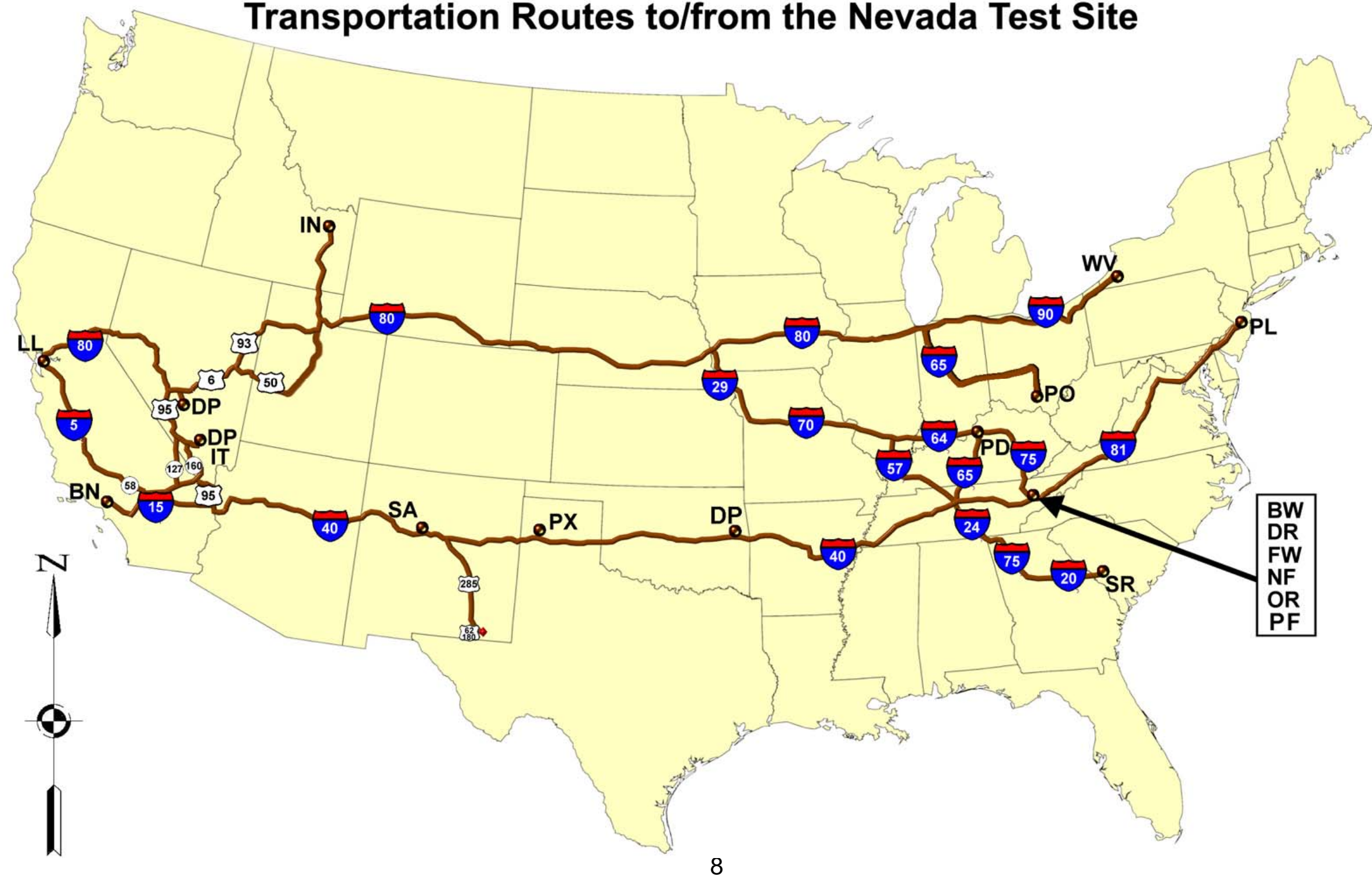




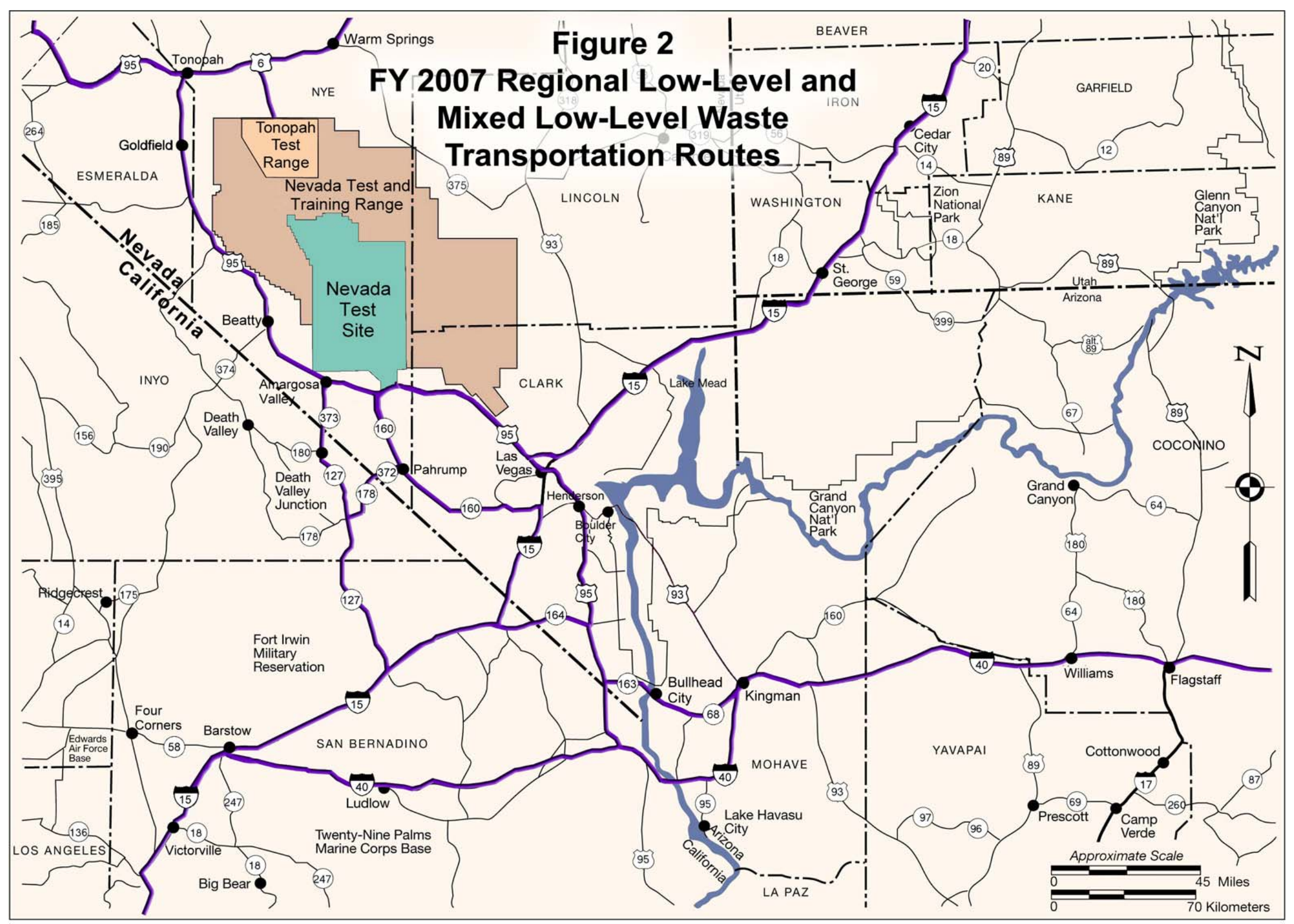


Table 8. Shipment Summary of Off-site, Inbound Regional Routes for FY 2007

I-15, CA-127, CA-178, NV-372, NV-160, US-95

I-15, CA-127, NV-373, US-95

$\mathrm{I}-15, \mathrm{NV}-160, \mathrm{US}-95$

I-40, I-15, CA-127, NV-373, US-95

$\mathrm{I}-40, \mathrm{I}-15, \mathrm{NV}-160, \mathrm{US}-95$

I-40, US-93, AZ-68, NV-163, US-95, NV-164, I-15, NV-160, US-95

I-40, US-93, AZ-68, NV-163, US-95, US-93, I-515, US-95 (SPAGHETTI BOWL)

I-40, US-95, NV-164, I-15, CA-127, NV-373, US-95

$\mathrm{I}-40$, US-95, NV-164, I-15, NV-160, US-95

I-80, US-93-ALT, US-6, US-95

$\mathrm{I}-80$, US-95

US-50, US-6/50, US-6, US-95

US-6, US-95 (TTR)

US-93, US-6, US-95

US-95 (CREECH AFB)

\begin{tabular}{|r|r|r|r|r|r|r|r|r|r|r|r|r|r|r|r|r|r|}
\hline & BN & BW & DP & DR & FW & IN & LL & NF & OR & PD & PF & PL & PO & PX & SA & SR & WV \\
\hline & & & & & & & & & & & & & 1 & & & & \\
\hline & 17 & & & & & & 11 & & & & & & & & & & \\
\hline & & & & & & & 1 & & & & & & & & & & \\
\hline & & & & & & & & & & & & & 3 & & & & \\
\hline & & & & & & & & & & & & & & & & & \\
\hline
\end{tabular}




\subsection{Transportation Route Reporting}

As a result of obligations made by former DOE Secretary Richardson, the transportation of inbound LLW shipments through the Las Vegas I-15 and US-95 Interchange (Spaghetti Bowl) has substantially decreased since FY 2000.

Due to the events of September 11, 2001, tractor trailers are no longer allowed to travel across Hoover Dam. The U.S. Department of Energy, National Nuclear Security Administration Nevada Site Office (NNSA/NSO) continues to engage in discussions with the generators regarding avoidance of the Spaghetti Bowl. The NTS Waste Acceptance Criteria includes wording requiring generators to notify their carriers to avoid Las Vegas, Nevada.

However, on November 16, 2006, two (2) LLW shipments en route from the Savannah River Site to the NTS traveled through the Spaghetti Bowl. The incident was researched thoroughly and the generator implemented required corrective actions to ensure there were no recurrences.

NNSA/NSO continues to honor an additional obligation made by former Secretary Richardson, and endorsed by the current administration, by preparing quarterly reports disclosing which routes transporters used to reach the NTS. These reports may be found on the Internet at

http://www.nv.doe.gov/emprograms/environment/wastemanagement/quarterlyrepo rts.aspx

\subsection{INCIDENTIACCIDENT DATA}

For the purpose of this report, an incident is defined as a traffic-related accident, a load shift, or a reported leaking/breached package which occurs during transportation.

Generators are instructed to notify the NNSA/NSO Assistant Manager of Environmental Management whenever a discrepancy, non-compliance, or inadequate performance is identified; or if a transportation incident or emergency situation occurs. There were two (2) U.S. Department of Transportation reportable transportation incidents in FY 2007.

- On February 6, 2007 at I-40 Mile Marker 68, outside of Clinton, OK, after being struck by another vehicle, a flatbed truck transporting LLW from Gore, OK to the NTS rolled onto its side. The container was damaged; but did not sustain a breach. The package was returned to its origination point, where the drums were repackaged and eventually shipped to the NTS.

- On February 9, 2007, during offloading operations of a cargo container, contamination was found on the trailer floor. Upon further investigation, liquid was found coming out of the bottom of the cargo container. The trailer was 
decontaminated and released. The appropriate notifications were made to the National Response Center pursuant to 49 CFR, §171.15 and §171.16.

National Security Technologies, LLC (NSTec) personnel control NNSA/NSO waste receipt and disposal activities at the NTS and are responsible for notifying appropriate personnel regarding any non-compliant or refused radioactive waste shipments. NSTec personnel also immediately notify generators in the event of any shipping paper discrepancies.

Below is a summary of issues observed during waste receipt and disposal activities in FY 2007. These issues are reported to the generators who then implement appropriate corrective actions to prevent recurrence.

- A package was received with two 4"x6" holes in the lower front side of the softsided waste container. No contamination was detected.

- After arrival, a cargo container was observed leaking liquid. No radiological contamination was detected in the leaking liquid. The container was returned to the generator. The vehicle driver contacted the National Response Center pursuant to 49 CFR, $\$ 171.15$, however it was not a DOT reportable event.

- A shipment arrived at NTS and drivers indicated that they took a route that took them through the Las Vegas valley via the northern portion of Clark County215 to US-95 North.

- A shipping manifest contained a discrepancy between the label on one (1) waste package and the shipping manifest. The manifest listed a Transport Index (TI) of 5.8, while the waste package label listed a TI of 4.2. The correct TI for the package was 4.2.

- Discrepancies between dose rates listed on the Package, Storage, and Disposal Request (PSDR) and actual dose for shipments were observed during our pre-entry and offloading surveys. Contact dose readings listed on the PDSR were much lower than what those measured.

- A shipment arrived without a hardcopy of the PSDR.

- A PSDR for a shipment listed incorrect number of packages.

- Shipping papers did not contain the PSDR or LLW Certification Statements.

\subsection{EVALUATION OF SHIPPING CAMPAIGNS}

Two of the 1,136 off-site inbound and none of the 11 off-site outbound shipments experienced incidents while in transit to/from the NTS. None of the 130 on-site transfers experienced incidents while being transported on the NTS. All generator shipping campaigns were considered successful.

One outbound shipment of MLLW to EnergySolutions generated a notice of deficiency from the State of Utah Department of Environmental Quality concerning missing hazard labels. NSTec researched the occurrence, implemented corrective actions, and reported back to the State of Utah - which then closed the matter. All outbound shipping campaigns were considered successful. 


\subsection{REFERENCES}

The primary sources of shipment information in this report are records kept by the NSTec Waste Management Program, who manages the NTS RWMS at Area 3 and Area 5. These records provide detailed information on each shipment of LLW and MLLW (dates received, generators, number and type of waste packages, volumes, weight, carrier, and final disposition of shipments). In addition, incident and accident information is gathered by reviewing other NSTec and NNSA/NSO correspondence and through personal communication with NNSA/NSO managers, NSTec management and program personnel, representatives from the waste generator facilities, and carrier personnel. Route information is gathered from quarterly routing reports generated by NNSA/NSO.

The following source documents are incorporated by reference:

- $\quad$ U.S. Department of Energy, Nevada Operations Office, "Final Environmental Impact Statement for the Nevada Test Site and Off-Site Locations in the State of Nevada" DOE/EIS 0243, Las Vegas, Nevada, August 1996.

- $\quad$ U.S. Department of Energy, Nevada Operations Office, "Mitigation Action Plan - Final Environmental Impact Statement for the Nevada Test Site and Off-Site Locations in the State of Nevada" DOE/EIS 0243, Las Vegas, Nevada, February 1997.

- U.S. Department of Transportation Regulations, 49 CFR, "Transportation," Code of Federal Regulations, Office of the Federal Register, National Archives and Records Administration, U.S. Government Printing Office, Washington, DC, 1998

\subsection{POINTS OF CONTACT}

Please contact the following personnel for questions concerning the transportation of radioactive waste at the NTS or for requests for information relating to waste management and NNSA/NSO operations.

\section{WASTE MANAGEMENT}

E. Frank DiSanza, Federal Project Director

U.S. Department of Energy

National Nuclear Security Administration

Nevada Site Office

Waste Management Project

P.O. Box 98518

Las Vegas, NV 89193-8518

(702) 295-5855 


\subsection{ACRONYM LIST}

$\begin{array}{ll}\mathbf{f t}^{3} & \text { Cubic Feet } \\ \mathbf{C F R} & \text { Code of Federal Regulations } \\ \text { DOE } & \text { U.S. Department of Energy } \\ \mathbf{d p m} & \text { Disintegrations per minute } \\ \text { EPA } & \text { U.S. Environmental Protection Agency } \\ \text { FY } & \text { Fiscal Year } \\ \text { LLW } & \text { Low-Level Radioactive Waste } \\ \text { MLLW } & \text { Mixed Low-Level Radioactive Waste } \\ \text { NNSA/NSO } & \text { U.S. Department of Energy, National Nuclear Security } \\ & \text { Administration Nevada Site Office } \\ \text { NRC } & \text { U.S. Nuclear Regulatory Commission } \\ \text { NSTec } & \text { National Security Technologies, LLC } \\ \text { NTS } & \text { Nevada Test Site } \\ \text { PSDR } & \text { Package, Storage, and Disposal Request } \\ \text { RWMS } & \text { Radioactive Waste Management Sites } \\ \text { TRU } & \text { Transuranic Waste } \\ \text { WIPP } & \text { Waste Isolation Pilot Plant }\end{array}$

\subsection{DISTRIBUTION LIST}

U.S. Department of Energy

National Nuclear Security Administration

Nevada Site Office

Technical Library

P.O. Box 98518

Las Vegas, NV 89193-8518

U.S. Department of Energy

National Nuclear Security Administration

Nevada Site Office

Public Reading Facility

c/o Nuclear Testing Archive

P.O. Box 98521

Las Vegas, NV 89193-8521

U.S. Department of Energy

Office of Scientific and Technical Information

P.O. Box 62

Oak Ridge, TN 37831-0062 